\title{
CATFISH KECIL UNIK, Corydoras sp. UNTUK AKUARIUM, TINGKAH LAKU BIOLOGI DAN REPRODUKSINYA
}

\author{
Darti Satyani*) \\ *) Loka Riset Budidaya Ikan Hias Air Tawar, Depok
}

\begin{abstract}
ABSTRAK
Corydoras sp. termasuk dalam familia Collichthyidae, kelas Siluridae dan sangat dikenal olah para hobiis ikan hias air tawar. Genus Corydoras yang berasal dari Amerika Selatan ini mempunyai banyak spesies tetapi yang banyak beredar dan sudah dibudidayakan ada 10 spesies yaitu C. aeneus, $C$. adolfoi, C. barbatus, C. paleatus, C. panda, C. pygmaeus, C. rabauti, C. septentrionalis, C. sterbai, dan C. sychri. Selain ukurannya yang umumnya kecil (maksimum 7,5 cm) dibandingkan dengan jenis catfish lain, jenis ini mempunyai dua baris sisik keras. Bentuk badannya kompak agak pipih ke samping dengan mulut menghadap ke bawah. Hidup merayap di dasar pada suhu $24^{\circ} \mathrm{C}--$ $28^{\circ} \mathrm{C}$ (tergantung spesiesnya); pH 7,0--7,5; dan hardness sekitar $10^{\circ} \mathrm{dH}$. Disebut "tukang bersihbersih" karena senang membersihkan dinding akuarium dengan mulutnya. Tingkah laku reproduksinya amat unik. Sebelum ovulasi induk betina akan menempatkan mulutnya kearah genital induk jantan yang dikenal dengan "posisi T" dan akan mengisap spermanya. Sperma ini akan dilepas melewati usus bersama dengan lepasnya telur kedalam "kantong" yang dibentuk oleh kedua sirip perutnya. Pembuahan efektif terjadi di sini. Kemudian telur akan dilekatkan ke substrat atau objek (daun, batu datar, dan sebagainya) yang sebelumnya telah dibersihkan oleh induk jantannya. Telur yang ditinggalkan akan menetas di substrat bila kondisi airnya sesuai dan cukup baik.
\end{abstract}

\section{KATAKUNCl: Corydoras, catfish, posisi T, kantong telur}

\section{PENDAHULUAN}

Ikan hias air tawar akhir-akhir ini sudah amat populer sebagai mata dagangan baik lokal maupun ekspor. Semakin banyaknya penggemar atau hobiis yang memelihara ikan hias komoditas ini semakin berharga secara ekonomis.
Di antara ratusan jenis ikan hias air tawar, Corydoras termasuk yang cukup terkenal dan amat bagus untuk komunitas akuarium. Banyak peternak atau pembudidaya yang membiakkan dan memeliharanya, dan pasarnya pun cukup bagus.

Ikan corydoras berasal dari perairan Amerika Selatan dan telah diperdagangkan ke seluruh dunia dengan banyak spesies. Sterba (1983) mencatat ada 95 spesies sementara yang terakhir Matsuzaka (1993) dalam Kohda et al. (1995) telah menyatakan genus ini mempunyai 120 spesies. Namun demikian yang masuk pasar saat ini terutama yang sudah dibudidayakan di Indonesia khususnya daerah Jabodetabek adalah 10 spesies yaitu C. aeneus, C. adolfoi, C. barbatus, C. paleatus, C. panda, C. pygmaeus, C. rabauti, C. septentrionalis, C. sterbai, dan C. sychri. Ukuran ikan jenis ini cukup kecil maksimal $7,5 \mathrm{~cm}$; sehingga amat cocok untuk akuarium. Dibandingkan dengan ikan catfish lain yang kebanyakan tidak bersisik, Corydoras mempunyai dua baris sisik besar. Sirip dadanya dilengkapi pula dengan tulang keras sebagai senjata (Sterba, 1983; Alderton, 1997).

Tingkah laku ikan ini amat unik selain senang merayap dan membersihkan dinding akuarium dengan mulutnya, kelakuan saat pemijahannya amat menarik untuk diamati (Axelrod \& Vordenwinkler, 1983; Sakurai et al., 1990; Kohda et al., 1995). Pemijahan yang terjadi melalui proses perkawinan yang amat unik yaitu dengan adanya pengisapan sperma oleh induk betina yang dikenal dengan "posisi T" (Kohda et al., 1995). Pembuahan dalam "kantong" yang dibentuk dari pasangan sirip perut untuk kemudian telur yang sudah dibuahi diletakkan di sarang (substrat) atau objek.

\section{BIOLOGI Corydoras sp.}

Genus Corydoras berasal dari perairan Amerika Selatan, yaitu daerah Brazil, Trinidad sampai Argentina (Alderton, 1997; Axelrod et al., 1995; Sakurai et al., 1990). Termasuk dalam famili Collichthyidae kelas Siluridae. Ukuran ikan ini relatif kecil dengan maksimum 7,5 cm. Pada yang dewasa umumnya ikan betina lebih besar dan gendut dari yang jantan yang lebih langsing. Sirip perut ikan jantan lebih lancip daripada yang betina yang lebih 
lebar dan panjang. Hidupnya merayap di dasar perairan dengan suhu optimalnya $24^{\circ} \mathrm{C}-28^{\circ} \mathrm{C}$ (tergantung spesies); pH antara 7,0--7,5; dan hardness $10^{\circ} \mathrm{dH}$ (Alderton, 1997; Axelrod et al., 1995; Mills, 1986; Sakurai et al., 1990). Ikan ini juga dapat hidup dalam air yang miskin oksigen karena dapat mengambilnya langsung dari atmosfir melalui mulutnya.

Bentuk badan kompak, bungkuk di punggung, agak pipih ke samping dengan mulut menghadap ke bawah dan dilengkapi dengan sungut atau kumis khas kelompok "Catfish". Sungut berjumlah 2 (dua) pasang di atas dan di bawah mulut berfungsi sebagai sensor atau radar untuk mencari makan maupun saat perkawinan (Geis, 2000). Tidak seperti kebanyakan catfish yang tidak besisik, Corydoras badannya diliputi oleh dua baris sisik besar yang disebut plate (Sterba, 1983). Sirip dada dan perut sepasang, sementara sirip yang lain tunggal. Sirip dada jari-jari pertamanya terdiri atas tulang yang lancip dan keras digunakan sebagai senjata. Corydoras juga sering mengeluarkan bunyi seperti ikan catfish lain, terutama saat pemijahan atau stres (ditangkap). Menurut Geis (2000), bunyi terjadi dari gesekan pada sendi sirip dengan gelembung renang sebagai pengeras (sound system).

Corydoras bersifat omnivora tetapi senang pakan alami. Pakannya adalah cacing, kutu air, maupun hewan air lain yang kecil. Ikan ini juga menggunakan usus untuk bernafas, mengambil udara melalui mulut dan melewati perut sampai keujung usus (Kohda et al., 1997). Oksigen akan terserap langsung ke peredaran darah melalui usus yang sudah termodifikasi dengan banyak pembuluh darah (Sakurai et al., 1990; Bailey \& Sandford, 1999). Kemampuan inilah yang akan memfasilitasi dalam melewatkan sperma secara cepat saat pemijahan.

Genus ini mempunyai banyak spesies. Menurut Sterba (1983), tercatat ada 95 spesies tetapi Matsuzaka (1993) dalam Kohda et al. (1995) telah menemukan ada 120 spesies. Namun demikian, yang banyak beredar di pasar dan sudah dibudidayakan di Indonesia khususnya daerah Jabodetabek adalah sekitar 10 spesies dan hanya 4 (empat) spesies yang banyak dibudidayakan di Jabodetabek, yaitu: C. aeneus, C. adolfoi, C. barbatus, C. paleatus, C. panda, C. pygmaeus, C. rabauti, C. septentrionalis, C. sterbai, dan C. sychri. Dari 10 spesies terdapat lagi varietas albino yaitu pada $C$. aeneus, $C$. paleatus, dan C. sterbai.

C. aeneus disebut juga sebagai Bronze Corydoras. Warnanya adalah coklat hijau kemerahan seperti perunggu. Ukuran maksimalnya $6,0 \mathrm{~cm}$. M empunyai varietas albino dengan badan putih dan mata merah.
C. adolfoi dengan nama umum Adolfo's Cory. Ukuran maksimalnya $6,0 \mathrm{~cm}$. Warnanya putih kebiruan dengan pita hitam vertikal pada daerah mata. Pita ini terdapat membujur di punggung mulai dari ujung sirip punggung sampai ke pangkal ekor. Ada warna kuning sampai merah terang di antara kedua pita tersebut.

C. barbatus dengan nama umum Giant Corydoras atau Barbatus Catfish. Merupakan Corydoras yang berukuran paling besar yaitu mencapai $8 \mathrm{~cm}$. Disebut juga "King of Corys". Warnanya coklat dengan bercak hijau kehitaman di seluruh tubuh sampai ke sirip-siripnya.

C. paleatus disebut sebagai Peppered Corydoras. Spesies dengan habitat bersuhu optimum yang lebih rendah dari yang lain $\left(18^{\circ} \mathrm{C}--20^{\circ} \mathrm{C}\right)$, terutama saat pemijahan (Geis, 2000). Warnanya coklat gelap, lebih gelap dari C. aeneus. Di sekitar kepala warna agak kebiruan. Ukuran maksimalnya $7,5 \mathrm{~cm}$. Varietas albino berwarna putih dengan mata merah terang.

C. panda atau Panda's Cory. Warna jenis ini putih agak kemerahan (pink) dengan pita atau garis lebar melintang di daerah kepala dan ekor. Sirip punggung juga hitam. Ukurannya mencapai $5,0 \mathrm{~cm}$; yang kecil warnanya lebih terang dan bagus dari yang besar, sehingga yang laku di pasaran umumnya yang ukuran kecil di bawah $5,0 \mathrm{~cm}$.

C. pygmaeus atau Pygmy Cory. Ukuran maksimalnya hanya 3,0 cm. Warnanya kuning mengkilat agak coklat hijau seperti perunggu terang. Ciri khasnya adanya pita hitam di tengah badan membujur mulai dari ujung mulut sampai ke pangkal ekor.

C. rabauti dengan nama umum Myer's Catfish. Ukuran maksimal $6,0 \mathrm{~cm}$. Warnanya hijau kehitaman dengan punggung yang agak lebih gelap. Matanya relatif besar dibanding Corydoras lainnya.

C. septentrionalis atau biasa disebut Southern Green Cory. Ukuran maksimal 6,0 cm. Warnanya hijau agak gelap dengan bercak lebar hijau kehitaman di tiga tempat yaitu ujung daerah kepala, tengah, dan badan belakang dekat ekor. Bentuk badannya lebih panjang atau langsing dibanding jenis yang lain.

C. sterbai disebut juga Sterba's Cory. Warnanya coklat dengan lurik (titik-titik halus berjajar) coklat tua. Sirip dada dan perut berwarna jingga terang. Ukuran dapat sampai 7,5 cm. Varietas albino luriknya tidak jelas.

C. sychri yang disebut juga Dotted Cory. Ukuran maksimal adalah $5,0 \mathrm{~cm}$. Warnanya putih dengan bintikbintik coklat hitam di seluruh tubuhnya. Ada pita lebar vertikal memotong daerah mata dari atas ke bawah. 


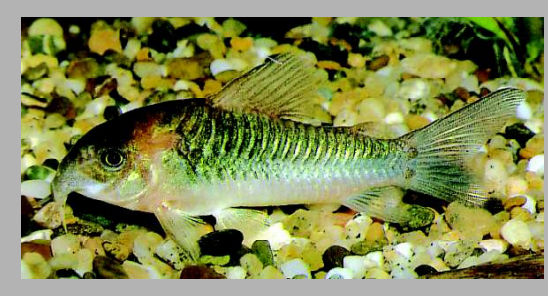

C. aeneus

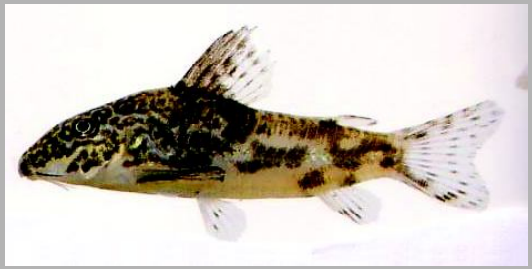

C. barbatus

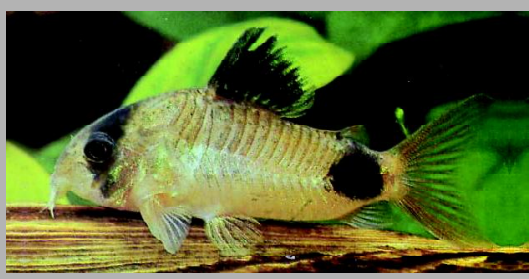

C. panda

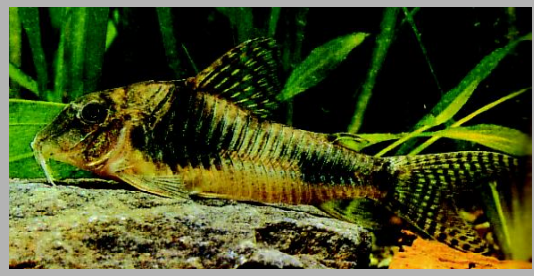

C. septentrionalis

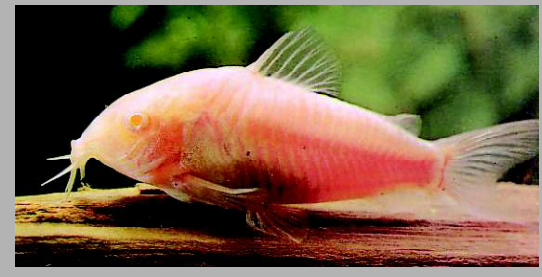

C. aeneus var. albino

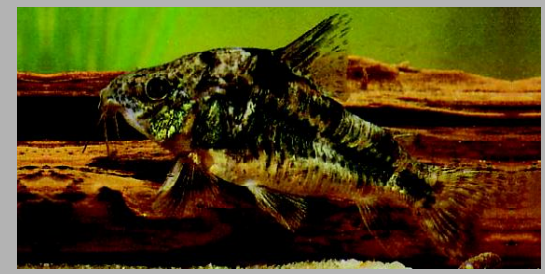

C. paleatus

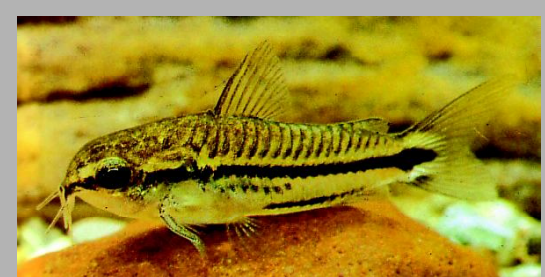

C. pygmaeus

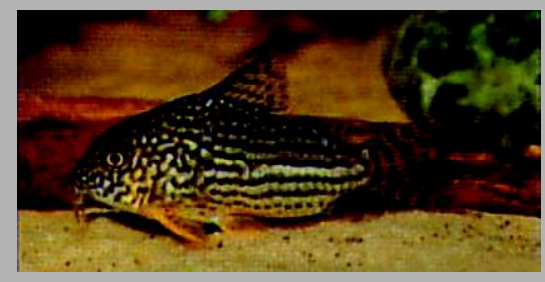

C. sterbai

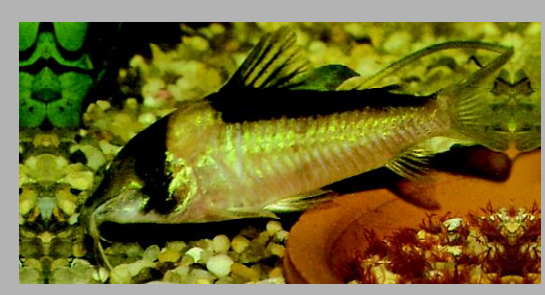

C. adolfoi

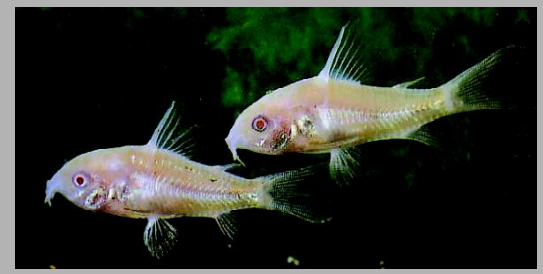

C. paleatus var. albino

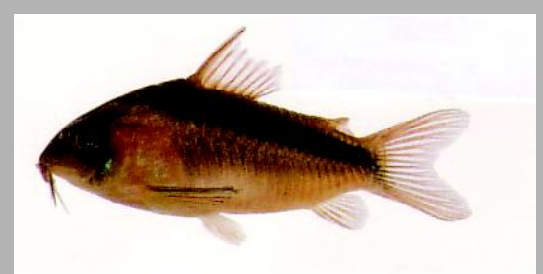

C. rabauti

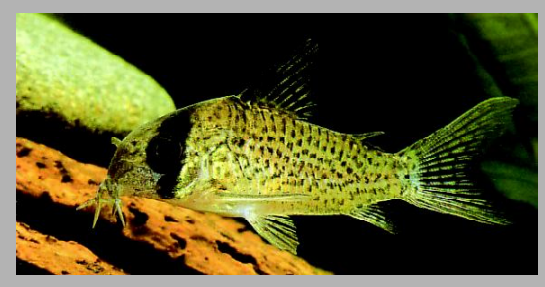

C. sychri

Gambar 1. Jenis Corydoras yang sudah dibudidayakan di Indonesia dan sudah diekspor ke manca negara (dari Axelrod et al., 1995; Sakurai et al., 1990; Bailey \& Sandford, 1999)

\section{TINGKAH LAKU DAN REPRODUKSI}

Corydoras merupakan ikan dasar dan senang merayap. Pakan yang tenggelam atau di dasar merupakan yang paling baik untuknya seperti cacing sutera (Tubifex sp.), cacing darah (Chironomussp.), atau pelet. Pada waktu kecil ikan ini senang berkelompok terutama dekat atau pada substrat, tetapi sesudah dewasa agak solitair. Walaupun demikian di alamnya menurut Sakurai et al. (1990) Corydoras yang sejenis atau sewarna akan berenang dalam rombongan.

Ikan Corydoras amat sosial dan damai, tidak agresif baik sesama teman maupun dengan ikan jenis lainnya. Mempunyai kebiasaan menyapu atau membersihkan dinding akuarium dengan mulutnya, sehingga disebut "tukang bersih-bersih". Kotoran hasil sapuannya sering teronggok di dasar akuarium.

Tingkah laku reproduksinya juga sangat unik. Biasanya dipijahkan secara massal dalam bak atau akuarium dengan perbandingan jantan dan betina 1:3 atau 1:4. Waktu memijah adalah saat musim penghujan. Sebelum memijah induk jantan dan betina yang sudah matang gonad akan berenang berendengan mencari tempat untuk meletakkan telur (sarang). Waktu bertelur biasanya pukul 05.00--07.00 pagi (setelah subuh sampai matahari terbit). Walaupun termasuk ikan dasar tetapi untuk tempat telur biasanya dipilih di kolom air, pada dinding akuarium, potongan paralon yang digantung, batang, dan permukaan daun atau objek lain. Peternak umumnya memberikan potongan paralon sebagai sarang. Tempat tersebut akan dibersihkan permukaannya dengan mulut, jantan akan lebih aktif dari 
yang betina (Axelrod \& Vordenwinkler, 1983).

Sesudah selesai membersihkan tempat telur, induk akan aktif berenang kesana kemari dan sesekali mereka bersinggungan. Kadang mengeluarkan suara. Sebelum ovulasi terjadi induk betina akan menempatkan mulutnya di lubang genital jantannya dan dikenal dengan "Posisi T" dan sperma akan diisapnya (Kohda et al., 1995; Bailey \& Sandford, 1999).

Ovulasi akan terjadi setelah itu dan induk betina akan diam di dasar selama 1,0--1,5 menit, telur yang keluar sebanyak 2--5 butir (Sterba, 1983; Geis, 2000). Telur ini akan ditempatkan di "kantong" yang dibentuk oleh pasangan sirip perut yang dibengkokkan (seperti tangan ditangkupkan). Setelah itu baru induk betina membawanya ke tempat objek yang sudah dibersihkan dan dilekatkan di situ. Sementara induk jantan akan selalu menunggu di belakang betina untuk proses ulang. Proses ini akan berulang sampai semua telur terovulasi yaitu sebanyak 50--200 butir sekali pemijahan tergantung dari spesiesnya (Sterba, 1983; Sakurai et al., 1990; Bailey \& Sandford, 1999). Telur-telur akan ditinggalkan dan tidak dirawat oleh induknya.

Ada banyak teori mengenai bagaimana cara pembuahan pada Corydoras ini. Ada pendapat sperma disemprot dari mulut ke bawah badan betina, pada saat ia diam di dasar wadah, kemudian membuahi telur di "kantong". Pendapat lain adalah sperma disemprotkan ke tempat telur yang disediakan, lalu dibuahi di tempat itu. Ada lagi pendapat bahwa sperma mengalir sepanjang badan betina sampai ke "kantong" (Axelrod \& Vordenwinkler, 1983; Sterba, 1983; Sakurai et al., 1990; Matsuzaka, 1993 dalam Kohda et al., 1995). Tetapi dari penelitian Kohda et al. (1995) yang mengikuti jalan sperma dengan cairan berwarna seperti Metil Biru didapatkan hasil bahwa sperma ini ditelan oleh induk betina melewati usus dan dikeluarkan bersamaan saat ovulasi kedalam "kantong". Pembuahan efektif terjadi di "kantong" itu pada saat induk berdiam di dasar wadah.

Tingkah laku reproduksi lebih dari 20 spesies Corydoras telah dilaporkan berlangsung seperti di atas dan diduga hampir semua spesies seperti itu (Kohda et al., 1995). Menurut Kohda et al. (1995), ada 3 (tiga) kondisi karakteristik yang dapat memfasilitasi proses pemijahan seperti di atas dapat berlangsung yaitu: (1) usus Corydoras yang amat pendek, (2) letak sirip perut yang amat dekat dengan lubang anus, dan (3) seringnya ikan mengambil udara lewat mulut untuk bernafas melalui usus. Kondisi nomor 3 (tiga) ini memberikan kebiasaan yang baik dalam melewatkan sperma melalui usus.

Telur Corydoras merupakan telur yang melekat (adhessive eggs). Perlekatannya amat erat dan susah untuk diambil atau dipindahkan dari objeknya. Para peternak umumnya memindahkan telur yang akan ditetaskan bersama dengan sarangnya atau induknya yang dipindahkan saat inkubasi. Telur akan menetas 2--3 hari tergantung dari suhu dan akan mulai berenang sesudah 5--6 hari.

Sayang bahwa informasi mengenai reproduksi ikan ini di alam atau habitatnya hampir tidak ada. Tetapi dengan adanya proses sperma yang aktif dalam "kantong" kecil diduga merupakan adaptasi terhadap lingkungan dalam memberikan efektivitas pembuahan. Demikian pula telur yang melekat sangat erat pada objek yang tidak mudah hanyut dalam air berarus yang merupakan habitat ikan Corydoras di alam (Burgess, 1992; Matsuzaka, 1993 dalam Kohda et al., 1995).

\section{PENUTUP}

Tingkah laku dari ikan Corydoras terutama dalam reproduksinya adalah amat unik. Proses yang unik yaitu menelan sperma untuk pembuahan yang efektif dalam "kantong" di mana telur yang akan ditempatkan diduga merupakan evolusi dari adaptasi ikan kecil dalam
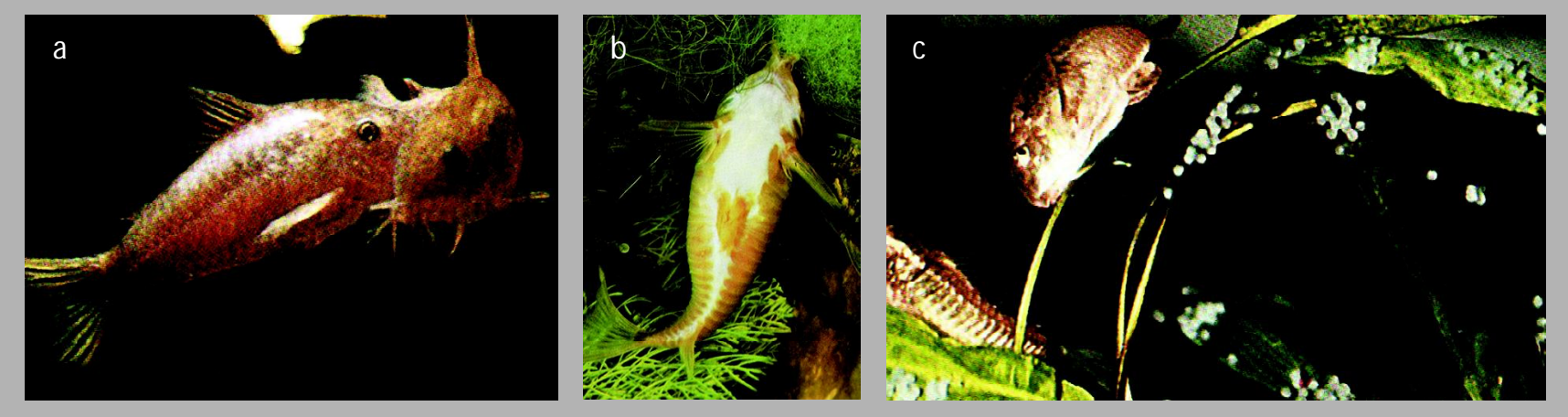

Gambar 2. Pemijahan pada C. aeneus.(Axelrod et al., 1995; Geis, 2000). (a. Posisi T. b. Kantong dari sirip perut yang ditangkupkan untuk membawa telur. c. Telur diletakkan pada batang/daun tanaman) 
lingkungan perairan yang berarus untuk mempertahankan generasinya.

\section{DAFTAR PUSTAKA}

Alderton, D. 1997. The Hamlin book of tropical freshwater fish. Reed International Book. Ltd. Singapore and Toronto. p. 100- 103.

Axelrod, H.R. and W. Vordenwinkler. 1983. Encyclopaedia of tropical fishes. TFH Publication, Inc. New YorkUSA. p. 151- 157.

Axelrod, H.R., W.E. Burgess, N. Pronek, and J.G. Wall's. Atlas of freshwater aquarium fishes. 1995. Eight edition. TFH Publication, Inc. New York-USA. 335 pp.

Bailey, M. dan G. Sandford. 1999. Illustrated encyclopedia, Aquarium fish identifier. Lorenz Books. New York. p. 24- 25.

Geis, R. 2000. Catfish keeping and breeding them in cap- tivity. TFH Publication, Inc. New York-USA. p. 3133.

Kohda, M. Tanimura, M.K. Nakamura, dan S. Yamagishi. 1995. Sperm drinking by female catfishes: a novel mode of insemination. Environmental Biology of fishes. 42: 1-6.

Mills, D. 1986. You and your aquarium. Alfred A. Knopf, Inc. Toronto, Canada. 75 pp.

Sakurai, A., Y. Sakamoto, and F. Mori. 1990. Aquarium fish of the world. Chronicle Book San Francisco. p. $229-253$.

Sterba, G. 1983. The Aquairist"t encyclopaedia. Blandfort Press. Dorset GDR. p. 175-176. 